\title{
Klavírní recitál dítěte mladšího školního věku v postojích rodiny. Replikace na ZUŠ
}

\author{
The piano recital of a child of younger school age in family attitudes. \\ A replication at a primary arts school
}

\author{
Zdeněk Vašíček
}

\begin{abstract}
Abstrakt: RVP ZUV žádá nejen inovaci, ale také ověření (autoevaluaci) její vhodnosti pro dítě. Vyjádření postojů rodičů a dítěte $\mathrm{k}$ inovaci může přispět $\mathrm{k}$ větší spolehlivosti takového ověření. Pokračoval jsem ve výzkumu na ZUŠ Tišnov, inovací zde byl klavírní recitál. Hlavní otázka zněla: „Je klavírní recitál vhodný pro dítě mladšího školního věku již na konci prvního ročníku studia?" Hlavní otázka byla operacionalizována do čtyř položek: 1. pozice hry na klavír v zájmové činnosti dítěte, 2. pomoc rodičů dítěti ve hře na klavír mimo školu, 3. náročnost př́ípravy klavírního recitálu pro dítě a 4. dopad uskutečněného klavírního recitálu na dítě. Robin, můj nový a perspektivní sedmiletý žák ve hře na klavír, se stal hlavním subjektem výzkumu. Jeho recitál byl ve srovnání s recitálem desetileté Marie z roku 2009 zjednodušen. Můj akční výzkum trval jeden školní rok. V souvislosti s rodinou (dítě, otec, matka) jsem použil dvě metody: a) pozorování (samozřjejmě hlavně dítěte) během mé výuky a b) interview. Provedl jsem triangulace odpovědí všech tří členů rodiny ve všech čtyř operacionalizovaných položkách. Hlavní otázka byla zodpovězena kladně.
\end{abstract}

Klíčová slova: RVP ZUV, základní umělecká škola, vzdělávací program, inovace, motivace, evaluace, postoje, rodina, klavírní recitál, dítě, mladší školní věk.

\begin{abstract}
The Framework Education Programme for Elementary Arts Education (in Czech: RVP ZUV) requires not only innovation but also verification (autoevaluation) of its suitability for a child. The expression of parental and childlike attitudes to an innovation can contribute to greater reliability of such verification. I continued my research at the Primary Art School in Tisnov, the innovation was a piano recital here. The main question sounded: "Does a piano recital represent a possible solution for a child of younger school age already at the end of his/her first year of study?" The main question was operationalised in four items: 1 . the position of piano playing in free time activities of the child, 2. the parental help to the child in piano playing outside of school, 3. the difficulty of piano-recital preparation for the child and 4. the impact of the realised piano recital on the child. Robin, my new and promising sevenyear-old male pupil in piano playing, became a main subject of the research. His recital was simplified with regard to the recital of ten-year-old Marie from 2009. My action research lasted one school year. I used two methods in connection with the family (child, father, mother): a) observation (naturally especially of the child) during my teaching and b) interview. I realised triangulations of answers of all the three family members in all the four operacionalised items. The main question was answered positively.
\end{abstract}

Keywords: FEP EAE, primary arts school, education programme, innovation, motivation, evaluation, attitudes, family, piano recital, child, younger school age 


\section{Teoretická východiska výzkumu}

Rámcový vzdělávací program pro základní umělecké vzdělávání (2010, s. 13 a 36; srov. též Helus, 2007, s. 187) žádá inovaci i ověření (autoevaluaci) její vhodnosti pro dítě. Pokusem o inovaci $v$ mé výuce na ZUŠ Tišnov byl klavírní recitál dítěte mladšího školního věku a pokusem o ověření uvedené inovace je můj níže představený výzkum. Postoje dítěte k inovaci mohou být poznamenány efektem sociální žádoucnosti (srov. v obecnosti Čáp \& Mareš, 2007, s. 431). To byl důvod, proč rodiče takř́íkajíc ,vtáhnout do autoevaluace“ spolu s dítětem. Souhrnné zjištění postojů rodičů a dítěte k inovaci mělo přispět ke spolehlivosti jejího ověření.

\section{Plán výzkumu}

Akčnímu výzkumu, zaměřenému na klavírní recitál dítěte mladšího školního věku, se jako učitel hry na klavír věnuji na ZUŠ Tišnov od roku 2006 (Vašíček, 2011, s. 1), tedy dlouhodobě. O dílčí fázi uvedeného výzkumu - školním roce 2010/2011 - pojednává tato instrumentální př́padová studie (srov. v obecnosti Hendl, 2008, s. 105). V souvislosti s rodinou (dítě, otec, matka) jsem použil dvě výzkumné metody. V době záŕí až květen metodu pozorování členů rodiny (samozřejmě hlavně dítěte) ve výuce. V době květen a červen metodu „rodinného“ interview v pořadí 1. dítě, 2. matka a 3. otec. Rodina vyjádřila souhlas s výzkumem i se zveřejněním této studie.

\section{Hlavní subjekt výzkumu Robin (a jeho rodiče)}

V této kapitole vyjadřuji své poznatky a postoje $\mathrm{k}$ dítěti a rodině jako učitel i výzkumník. Robin byl mým žákem v předmětu hra na klavír na ZUŠ Tišnov. Na klavír začal hrát po vstupu na tuto školu ve věku sedmi let. Dle obvyklé typologie (Pavelková, 2002, s. 49) se v mé výuce projevoval jako nadaný, pracovitý, dominantní, extravertní a bez viditelných př́znaků úzkostností. Pokud jde o hru na klavír, nastal u něho efekt zrychlení (obecně srov. Průcha, Walterová, \& Mareš, 2003, s. 14). Klavírním recitálem nadstandardně splnil úkoly svého ročníku na ZUŠ Tišnov. Po celý školní rok na ZUŠ Tišnov měl vzornou docházku. Rozhovory s rodiči ukázaly, že jejich syn se podobným způsobem jako v typologii výše projevuje i na ZŠ. Robin byl občanem České republiky a národnosti české. Pocházel ze střední vrstvy, z majoritní společnosti, z úplného manželství a nebyl jedináček. Rodiče Robina nebyli povoláním hudebníky ani učiteli hudby, ale chodili v dětství do hudebního oboru LŠU. Rodiče výuku pozorně sledovali. Splňovali charakteristiku těch, kdo si na dítě udělají čas (srov. Vymětal, 2004, s. 134). Kladný emoční vztah otce a matky k synovi byl viditelný. V dnešní rodině „mizí“ otec (Možný, 2002, s. 145), tady nemizel. Robinův recitál otec natočil na DVD.

\section{Hlavní výzkumná otázka a z ní odvozené položky}

Hlavní otázka zněla: „Je klavírní recitál vhodný pro dítě mladšího školního věku již na konci prvního ročníku studia?“ Na hlavní otázku jsem jako učitel mohl s přihlédnutím k výše uvedenému chladně odpovědět ,Je!“‘, doložit to školními dokumenty i DVD Robina a výzkum si už odpustit. To by však znamenalo ochuzení o to nejžádanější. $O$ autentické postoje rodiny včetně samotného Robina k inovaci. Proto jsem pokračoval ve výzkumu. 
Hlavní otázku jsem operacionalizoval do čtyř položek a za nimi uvedl očekávané ideály:

1. Pozice hry na klavír v zájmové činnosti dítěte (ideál: výrazná). (Viz kapitolu 5.)

2. Pomoc rodičů dítěti ve hře na klavír mimo školu (ideál: účinná). (Viz kapitolu 6.)

3. Náročnost přípravy klavírního recitálu pro dítě (ideál: únosná). (Viz kapitolu 7.)

4. Dopad uskutečněného klavírního recitálu na dítě (ideál: přiznivý). (Viz kapitolu 8.)

Definice:

- Definice 1: „Klavírní recitál dítěte má délku 25 minut, s průvodním slovem 35 minut. Zahrnuje ze dvou třetin hru sólovou, z jedné třetiny hru komorní. Obsahuje autorskou více či méně vážnou hudební tvorbu na úrovni daného ročníku studia na ZUŠ Tišnov či na úrovni poněkud vyšší.“ Pro srovnání i pro úplnost: klavírní recitál Marie v roce 2009 měl celkovou délku 45 minut (srov. Vašíček, 2011), klavírní recitál Robina záměrně o 10 minut méně.

- Definice 2: Mladší školní věk je ,věk, který se dá vymezit jednak časově (přibližně od 6 do 10 let), jednak docházkou (1.-4. ročník školní docházky)“ (Průcha, Walterová, \& Mareš, 2003, s. 128).

- Definice 3: Postoj je „hodnotící vztah zaujímaný jednotlivcem vůči okolnímu světu, jiným subjektům i sobě samému“" (Průcha, Walterová, \& Mareš, 2003, s. 171).

- Definice 4: Nukleární rodinu „tvoří nejbližší příbuzní, tj. oba rodiče a děti““ (Průcha, Walterová, \& Mareš, 2003, s. 202). Uvést postoje hlavního subjektu výzkumu Robina i jeho otce a matky bylo vhodné mimo jiné kvůli triangulaci. Sourozence Robina jsem do výzkumu z praktických důvodů nezahrnul.

\section{Pozice hry na klavír v zájmové činnosti dítěte}

Postoje Robina. „Hra na klavír mě baví.“ „Chci být učitelem hry na klavír.“ Robin pak popisuje své aktivity. Doma se nemusí moc připravovat do ZŠ, učení mu totiž jde „dost samo“. U počítače je jen občas, na televizi se nedívá víc než hodinu denně. „Rád čtu detektivky.“ Doma cvičí na keyboard. Ten někdy tlumí, aby nerušil. Postoje otce. „Ta hudba se synovi líbí." Sportuje, ale hudba ho baví víc. Otec ještě doplňuje, že Robin se rychle učí nové věci. U počítače ho rodiče ,sleduji“‘. Na televizi se nedívá víc než hodinu denně. Čte pohádkové knihy. Robin „,nebyl pod nátlakem, proto měl chut““. Postoje matky. „S klavírem je Robin spokojen, netápe.“ Matka doplňuje, že na ZŠ to Robinovi jde a doma už se nemusí moc učit. Jen si napíše úkol. Má víc času na hru na klavír, která ZŠ nekonkuruje. Čte dobrodružné knihy. „V počítači ho krotíme“, na televizi se nedívá víc než hodinu denně. „Rád předvede, když něco umí. I v klavíru.“ Hledal si nějakého koníčka, jako má jeho sourozenec. Robin však nesnáší nátlak, proto odešel ze sportovního kroužku. V klavíru to bylo jiné. A tak ,syn chodí na klavír, jako jiní na tenis“. Výsledek. Pozice hry na klavír v zájmové činnosti dítěte byla výrazná.

\section{Pomoc rodičů dítěti ve hře na klavír mimo školu}

Postoje Robina. Otec i matka mu občas dělali poradce. „Když jsem nepochopil nějakou notu, vysvětlili mi ji.“ Jeho rodiče totiž „hudbu slyší“. Otec a Robinův sourozenec hrají na jiné hudební nástroje než Robin, někdy spolu doma hráli a Robin se jim chtěl vyrovnat. Rodiče na 
něj nemusejí být přísní. Postoje otce. Robin má v hlavě zatím spoustu věcí. Když si hraje (s hračkami), je nutno ho „odchytit“ a přivést k úkolům. Ne snad př́sně, ale pevně. Otec dohlížel na kvalitu hudby. Navíc hrál v amatérském orchestru s Robinovým sourozencem, aby zvýšil hudební motivaci svých dětí. Organizoval účast rodiny na Robinových vystoupeních i recitálu. Postoje matky. Byla Robinovi „organizátorkou denní klavírní přípravy“ a „dílčím hudebním poradcem“. Rodiče musejí být přísní na syna jen občas. „Krotí“ ho, když provokuje. Diskuse. Rodiče pomáhali dítěti ve hře na klavír mimo školu slovem i činem. Jinak to nejde (srov. Judovina-Galperina, 2000, s. 37). Triangulace spíše potvrzuje účinnou pomoc rodičů dítěti. Výsledek. Pomoc rodičů dítěti ve hře na klavír mimo školu byla účinná.

\section{Náročnost př́ípravy klavírního recitálu pro dítě}

Postoje Robina. „Dalo se to zvládnout. Bylo to jen trochu víc práce. Spíš radost.“ Postoje otce. Když Robin šel kolem nástroje, hrál, „častěji hrál po kratších úsecích“. Občas měl otec obavu, aby syn „vše zažil a zvládl“. Postoje matky. Nebylo to pro Robina „nic extrémně jiného, než př́íprava na klavírní výuku“. Diskuse. Triangulace potvrdila u dítěte jistou zátěž, ale nikoli krajní. Výsledek. Náročnost př́pravy klavírního recitálu pro dítě byla únosná.

\section{Dopad uskutečněného klavírního recitálu na dítě}

Postoje Robina. Byl rád, že poznal a zvládl novou hudbu. „Bylo mi dobře. Nejvíc ze všeho mě potěšily potlesky.“ Postoje otce. Byl pyšný na Robina, že svůj recitál zvládl. „Syn byl nadšený. Motivuje ho to." Na recitálu se setkaly rodiny Robinova otce a matky poprvé po řadě let od svatby. Postoje matky. „Syna obdivuji.“ Robin po recitálu sám u sebe stoupl v ceně, je na sebe hrdější. „Nefrajeří", ale cítí se dobře. Diskuse. Triangulace potvrdila jen kladné emoce dítěte, otce i matky. Výsledek. Dopad uskutečněného klavírního recitálu na dítě byl př́znivý.

\section{Celkové výsledky}

Položky hlavní výzkumné otázky byly zodpovězeny takto:

1. Pozice hry na klavír v zájmové činnosti dítěte byla výrazná.

2. Pomoc rodičů dítěti ve hře na klavír mimo školu byla účinná.

3. Náročnost př́pravy klavírního recitálu pro dítě byla únosná.

4. Dopad uskutečněného klavírního recitálu na dítě byl př́znivý.

Jak vidno, všechny položky byly zodpovězeny kladně (ideálně). Lze tudíž provést shrnutí. Klavirní recitál na ZUŠ je vhodný pro dítě mladšího školního věku už na konci prvního ročníku studia. (Rozumí se, že za výše uvedených specifických podmínek.)

\section{Závěr}

Zbývá ověřit možnost klavírního recitálu dítěte ještě mladšího, než byl Robin. Tedy dítěte, které by mělo klavírní recitál už v době takzvané přípravné nástrojové výchovy (PNV) - ve věku šest let (či ještě méně?). V dlouhodobém akčním výzkumu na ZUŠ Tišnov na dané téma proto budu dále pokračovat. 


\section{Literatura}

Čáp, J., \& Mareš, J. (2007). Psychologie pro učitele. Praha: Portál.

Helus, Z. (2007). Sociálni psychologie pro pedagogy. Praha: Grada.

Hendl, J. (2008). Kvalitativni výzkum. Praha: Portál.

Judovina-Galperina, T. B. (2000). U klavíru bez slz aneb Jsem pedagog dètí. Brno: Lynx.

Možný, I. (2002). Sociologie rodiny. Praha: Sociologické nakladatelství.

Pavelková, I. (2002). Motivace žákio k učení. Praha: UK v Praze.

Pavelková, I. (2005). Žákovská nemotivovanost. In J. Vaštatková (Ed.), Pedagogický výzkum: Reflexe společenských potřeb a očekávání? (217-221). Olomouc: UP v Olomouci.

Průcha, J., Walterová, E., \& Mareš, J. (2003). Pedagogický slovník. Praha: Portál.

Rámcový vzdélávací program pro základni umélecké vzdělávání. (2010). Praha: VúP v Praze.

Vašíček, Z. (2011). Postoje rodiny ke klavírnímu recitálu dítěte mladšího školního věku na ZUŠ. In J.

Wernerová (Ed.), Kam směruje současný pedagogický výzkum? Sborník př̀spěvků XVIII.

celostátní konference $\check{C} A P V$ [CD-ROM]. Liberec: TU v Liberci.

Vymětal, J. (2004). Úzkost a strach u dětí. Praha: Portál.

\section{Kontakt}

MgA. et MgA., PhDr. Zdeněk Vašíček, Ph.D. et Ph.D.

\section{ZUŠ Tišnov}

Dvořáčkova 316, 66601 Tišnov

e-mail: zus@zustisnov.cz

zdenek.vasicek@c-box.cz

\section{Bibliografické údaje}

Vašíček, Z. (2011). Klavírní recitál dítěte mladšího školního věku v postojích rodiny. Replikace na ZUŠ. In T. Janík, P. Knecht, \& S. Šebestová (Eds.), Smíšený design v pedagogickém výzkumu: Sborník př́spěvků z 19. výroční konference České asociace pedagogického výzkumu (s. 223-227). Brno: Masarykova univerzita.

Dostupné z: http://www.ped.muni.cz/capv2011/sbornikprispevku/vasicek.pdf doi: 10.5817/PdF.P210-CAPV-2012-82 